\title{
MOGUĆNOSTI OSTVARIVANJA INKLUZIJE U ŠKOLSKOM KONTEKSTU ${ }^{1}$
}

\author{
Marija Marković ${ }^{2}$ \\ Univerzitet u Nišu, Filozofski fakultet u Nišu, Departman za pedagogiju
}

\begin{abstract}
Apstrakt: U radu se ukazuje na mogućnosti realizacije koncepta inkluzivnog obrazovanja u školskom kontekstu, kao sastavnog dela reforme školskog sistema kod nas. Ukazuje se na načine definisanja pojma inkluzije, na vrste posebnih potreba dece, kao i na načine realizacije koncepta inkluzivnog obrazovanja kod nas. Posebna pažnja posvećena je ukazivanju na specifičnosti različitih modela obrazovanja dece sa posebnim potrebama. Sa kritičkog aspekta analiziraju se i razmatraju pitanja vezana za potencijale školskog konteksta u ostvarivanju inkluzije. Centralni deo rada posvećen je realnim mogućnostima škole da odgovori na potrebe i izazove realizacije inkluzivnog obrazovanja, u smislu ukazivanja na neophodne preduslove, prednosti i slabosti koje u tom domenu karakterišu naš školski konktekst, kao i na potrebne promene u cilju uspešne realizacije inkluzivnog obrazovanja kod nas. Implementacija inkluzije u vaspitno-obrazovnim ustanovama čini polaznu osnovu za kreiranje inkluzivnog društva, pri čemu se u tom procesu promene u školi sagledavaju kao prioritet.
\end{abstract}

Ključne reči: : škola, inkluzivno obrazovanje, deca sa posebnim potrebama, nastavnici, vršnjaci.

\section{Uvod}

Savremene tendencije u obrazovanju ispoljene kroz ideju o društvu znanja, pluralističkom i demokratskom društvu, ističu važnost ostvarivanja prava na obrazovanje i uključivanja svakog pojedinca u obrazovanje. Srbija je donošenjem novog obrazovnog zakona - Zakona o osnovama sistema obrazovanja $i$ vaspitanja (2009), pokazala svoje opredeljenje ka sprovođenju obrazovne inkluzije, nediskriminaciji i

\footnotetext{
${ }^{1}$ Pripremljeno u okviru projekta Održivost identiteta Srba i nacionalnih manjina u pograničnim opštinama istočne i jugoistočne Srbije (179013), koji se realizuje na Univerzitetu u Nišu -Mašinski i Filozofski fakultet, a finansira ga Ministarstvo prosvete i nauke RS.
}

${ }^{2}$ marija.markovic@filozofski.rs 
drugim važnim principima na koje se obavezala potpisivanjem međunarodnih ugovora. Navedeni zakon usaglašen je sa međunarodnim konvencijama i predstavlja prvi i neophodan korak ka ostvarivanju prava na obrazovanje sve dece. Inkluzija u obrazovanju kod nas uvedena je od školske 2010/11. godine u sva odeljenja i sve škole u zemlji. Usvojena zakonska rešenja bitno utiču na promene u školskom kontekstu, što školu stavlja pred nove izazove.

Od posebne važnosti za inkluziju u obrazovanju jeste rano uključivanje dece sa posebnim potrebama u zajednicu i pružanje mogućnosti njihovog aktivnog učešća u svim tokovima društvenog života. To podrazumeva svojevrsnu pripremu zajednice za sprovođenje inkluzije, ali i motivisanost i osposobljenost aktera uključenih u njenu realizaciju. Svakako, kako bi se sprečila socijalna isključenost potrebno je sa intervencijama početi još u porodici i nastaviti sa kontinuiranim pružanjem podrške detetu s posebnim potrebama i njegovoj porodici kroz čitav proces institucionalnog vaspitno-obrazovnog rada (Rajović i Jovanović, 2016; Suzić, 2008).

\section{Određenje inkluzije}

Generalno gledano, moguće je razlikovati tri pristupa određenju inkluzije (Suzić, 2008):

1) Prema prvom pristupu, inkluzija se određuje kao najopštiji pojam i proces, u kome se segment nečega ili pojedinac u društvu posmatra kao deo celine. Istovremeno sa razvojem svesti o individualnom i socijalnom značaju obrazovanja i o vrednosti svakog pojedinca u takvom društvu, postepeno se osnažuje ideja o socijalnoj inkluziji koja se definiše kao „koncept, teorija, pokret, filozofija, politika, praksa, proces kojim se osigurava da svaki čovek (dete) kao član ljudske zajednice, bez obzira na iskustvo i životne okolnosti, može ostvariti svoje potencijale, učestvujući u svim segmentima života" (Đukić i Đermanov, 2011: 280).

2) Drugi pristup se odnosi na definisanje inkluzivnog vaspitanja i obrazovanja pod kojim se podrazumeva spontana ili intencionalna aktivnost individue ili društva kao proces učenja i poučavanja u kome dolazi do relativno trajnih i progresivnih promena u uslovima međusobne podrške i socijalne uključenosti. Dakle, reč je o procesu vaspitanja i obrazovanja sve dece, kao jednom od aspekata društvene ravnopravnosti, demokratije i participacije.

3) Tré́i, najuži, pristup podrazumeva razumevanje inkluzije kao humanog procesa uključivanja dece sa posebnim potrebama u redovne škole i celokupan društveni život. Imajući u vidu navedeno stanovište, prema vrstama posebnih potreba moguća je klasifikacija na (Ivančić, 2013; Kovačević, 2011): 1) decu sa oštećenjima vida, 2) decu sa oštećenjima sluha, 3) decu sa poremećajima govorno-jezičke komunikacije, 4) decu sa specifičnim teškoćama u učenju (disleksija, disgrafija, diskalkulija), 5) decu sa motoričkim poremećajima i hroničnim bolestima, 6) decu sa sniženim intelektualnim sposobnostima, 7) decu sa poremećajima u ponašanju uslovljenom organskim faktorima ili progredirajućim psihopatološkim stanjem, 8) 
decu sa poremećajem pažnje/hiperaktivnim ponašanjem, 9) decu sa poremećajima iz autističkog spektra,10) višestruko ometenu deca.

Osnovu vaspitno-obrazovnog rada sa decom sa posebnim potrebama predstavljaju pedagoški profil deteta i individualni obrazovni plan. Zadatak vaspitača, nastavnika ili stručnih saradnika jeste da prati razvoj i napredovanje svakog pojedinca u toku učenja, socijalnog razvoja, razvoja komunikacije i samostalnosti. Ukoliko se u toku praćenja ustanovi da dete ne napreduje, odnosno da ne ostvaruje ishode obrazovanja i vaspitanja, pristupa se prikupljanju podataka za pružanje odgovarajuće podrške u obrazovanju i vaspitanju. $\mathrm{Na}$ osnovu prikupljenih podataka učenika i dokumentacije, stručni saradnik u saradnji sa vaspitačem izrađuje pedagoški profil učenika. Pedagoški profil sadrži opis obrazovne situacije deteta i predstavlja osnovu za planiranje individualizovanog načina rada sa učenikom. Na osnovu pedagoškog profila učenika utvrđuju se područja u kojima postoji potreba za dodatnom podrškom u obrazovanju i vaspitanju i planira se otklanjanje fizičkih i komunikacijskih prepreka (Pravilnik o bližim uputstvima za utvrđivanje prava na individualni obrazovni plan, njegovu primenu i vrednovanje, 2009).

Individualni obrazovni plan predstavlja pismeni dokument ustanove, kojim se planira dodatna podrška u obrazovanju i vaspitanju ako prethodno prilagođavanje i otklanjanje komunikacijskih i fizičkih prepreka nisu doveli do ostvarivanja opštih ishoda obrazovanja i vaspitanja. Takav dokument sadrži: 1) lične podatke i kratak opis razvoja i obrazovne situacije deteta, 2) cilj obrazovno-vaspitnog rada, odnosno promenu koja dodatnom podrškom treba da se postigne u području u kome se dodatna podrška planira, 3 ) operacionalizovan opis podrške kroz niz pojedinačnih aktivnosti, odnosno koraka, 4) posebne standarde postignuća i prilagođene standarde za pojedine aktivnosti, kao i ishode tih aktivnosti, 5) lica koja će pružati podršku tokom realizacije pojedinačnih planiranih aktivnosti, 6) vremenski raspored, trajanje, odnosno učestalost za svaku meru podrške u toku planiranih aktivnosti. Pravo na individualni obrazovni plan ima pojedinac koji ima potrebu za dodatnom podrškom u obrazovanju i vaspitanju zbog teškoća u pristupanju, uključivanju ili napredovanju u vaspitno-obrazovnom radu, ako te teškoće utiču na ostvarivanje opštih ishoda obrazovanja i vaspitanja, a naročito ako pojedinac: 1) ima teskoće u učenju, 2) ima smetnje u razvoju ili invaliditet, 3) potiče, odnosno živi u socijalno nestimulativnoj sredini, ili 4) iz drugih razloga ostvaruje pravo na podršku u obrazovanju. Individualni obrazovni plan (IOP) se izrađuje prema obrazovnim potrebama konkretnog pojedinca i može da podrazumeva njegovo školovanje:

- po prilagođenom programu u kome se precizno planira cilj pružanja podrške, koja se odnosi na prilagođavanje i obogaćivanje prostora i uslova u kojima se uči, prilagođavanje metoda rada, udžbenika i nastavnih sredstava, obrazovno-vaspitnog procesa, prilagođavanje aktivnosti i njihovog rasporeda, kao i izbor lica koja pružaju podršku;

- po izmenjenom programu u kome se precizno planira prilagođavanje opštih ishoda obrazovanja i vaspitanja, prilagođavanje posebnih standarda postignuća učenika u odnosu na propisane i prilagođavanje sadržaja za jedan, više ili za sve predmete. 
- po obogaćenom ili proširenom programu koji se primenjuje za učenike sa izuzetnim sposobnostima (Pravilnik o bližim uputstvima za utvrđivanje prava na individualni obrazovni plan, njegovu primenu i vrednovanje, 2009).

Individualni obrazovni plan može da se donese za deo ili celokupan predškolski program, a u školi za deo ili oblast u okviru nastavnog predmeta, jedan nastavni predmet, grupu nastavnih predmeta ili za sve sadržaje, kao i za vannastavne aktivnosti (Pravilnik o bližim uputstvima za utvrđivanje prava na individualni obrazovni plan, njegovu primenu i vrednovanje, 2009).

\section{Modeli obrazovanja dece sa posebnim potrebama}

U svetu i kod nas prisutni su različiti obrazovni putevi i načini školovanja dece sa posebnim potrebama. Generalno gledano, kao moguće modele obrazovanja dece sa posebnim potrebama možemo razlikovati (Ivančić, 2013; Kovačević, 2011; Suzić, 2008):

1) strogo podvojeni model, koji podrazumeva institucionalno vaspitanje dece sa posebnim potrebama u okviru specijalnih škola, koje su potpuno odvojene od redovnih škola, što podrazumeva potpunu prostornu i socijalnu odvojenost dece sa posebnim potrebama od vršnjaka tipičnog razvoja. Dati model postojao je u bivšoj Jugoslaviji sve od Drugog svetskog rata do danas. Prednosti navedenog modela se ogledaju u stručnoj pomoći i uslovima školovanja prilagođenim deci sa posebnim potrebama, kao i olakšanoj dijagnostici, zbog postojanja stručnih timova koji mogu postaviti odgovarajuću dijagnozu i konstantno neposredno pratiti napredak deteta sa posebnim potrebama. Slabost datog modela ogleda se u segregaciji i etiketiranju dece sa posebnim potrebama, što rezultira njihovom socijalnom neprihvaćenošću i neprilagođenošću ako se školuju u specijalnoj školi bez kontakta s vršnjacima tipičnog razvoja.

2) model integracije, koji ima dve varijante. Prva varijanta odnosi se na delimičnu integraciju, koja podrazumeva postojanje specijalnih škola koje su odvojene od redovne, ali i postojanje odeljenja za učenike sa posebnim potrebama u okviru redovne škole. Prednost datog modela ogleda se u mogućnostima socijalne interakcije dece sa posebnim potrebama sa vršnjacima iz redovne nastave tokom odmora, zajedničkih izleta, ekskurzije itd., što im omogućava da se u određenoj meri socijalno adaptiraju. U školskoj praksi bivše Jugoslavije model je postojao za decu koja su imala lakša onesposobljenja ili hendikepe. Takva deca pohađala su odeljenja u sklopu redovne škole, dok su deca sa težim onesposobljenjima pohađala specijalne škole. Nedostatak datog modela ogleda se u mogućnosti samo delimičnog rešavanja problema segregacije dece sa posebnim potrebama. U okviru datog modela nema koedukacije, tako da su deca sa posebnim potrebama u redovnoj školi samo fizički prisutna, ali nema prave interakcije sa vršnjacima iz drugih odeljenja. Druga varijanta se odnosi na potpunu integraciju dece sa posebnim potrebama u odeljenja u okviru redovnih škola. Takav vid integracije podrazumeva da je najpre potrebno proceniti 
sposobnosti i mogućnosti deteta sa posebnim potrebama i tek kada ono pokaže određeni stepen prosečnosti može se uključiti u redovno odeljenje. Kao glavni nedostatak datog vida integracije navodi se to što ona podrazumeva prethodnu pripremu deteta i njegovo menjanje kako bi moglo biti uključeno u redovni vaspitno-obrazovni proces. Integracija ne podrazumeva bilo kakvu reformu obrazovnih institucija koja bi omogućila lakše uključivanje dece sa posebnim potrebama, već zahteva prethodnu pripremljenost deteta za dati proces. Pored toga, takav način uključivanja dece sa posebnim potrebama u redovne škole ne doprinosi promeni stavova prema ovoj deci (Stanisavljević-Petrović, 2013; Vujačić, 2005).

3) model inkluzije, koji ima dve varijante. U prvoj varijanti-modelu delimične inkluzije, učenici sa posebnim potrebama imaju svoj radni prostor uz učionicu, tako da jedno vreme borave u učionici redovne nastave, a povremeno u učionici specijalne nastave. Svi časovi, odmori i drugi uslovi isti su za sve učenike. Data varijanta modela inkluzije podrazumeva da u učionici specijalne nastave uz nastavnika redovne nastave imamo specijalnog pedagoga, kao i da oni međusobno sarađuju. Druga varijanta modela inkluzije - model potpune inkluzije smatra se najpoželjnijom. Data varijanta podrazumijeva da dete sa posebnim potrebama sve vreme pohađa nastavu sa decom u redovnoj nastavi. U učionici je pored nastavnika redovne po pravilu prisutan i nastavnik specijalne nastave, koji pomaže učeniku ili učenicima sa posebnim potrebama. Pored toga, ovakvu nastavu povremeno posećuje i u njoj učestvuje stručni tim koji služi za posebnu pomoć i konsultacije, za posebne intervencije, povremene preglede i funkcionalnu dijagnostiku. Prednosti datog modela su višestruke i obuhvataju: mogućnost socijalizacije uz svakodnevni život sa vršnjacima; razvoj osećaja međusobne brige i potrebe za podrškom vršnjaku sa posebnim potrebama, za uvažavanje i saradnju; nastavu za dete sa posebnim potrebama koje podrazumeva zajednički rad specijalnog pedagoga i nastavnika redovne nastave, zbog čega dete sa posebnim potrebama u redovnoj nastavi ima iste mogućnosti kao u specijalnoj školi; stvaranje obrazovnog konteksta u kome vršnjaci iz redovne nastave ne gube ništa jer njihov razredni nastavnik i dalje radi s njima, dok specijalni pedagog radi sa detetom sa posebnim potrebama, kao i mogućnost uključivanja deteta sa posebnim potrebama u sve aktivnosti redovnog programa u meri u kojoj je to izvodljivo.

Model inkluzije, nasuprot integraciji, podrazumeva pripremu i menjanje obrazovnog sistema a ne deteta, čime se pružaju mogućnosti uključivanja deteta u sve školske aktivnosti u meri u kojoj je to moguće, što doprinosi eliminisanju segregacije i odbacivanja ove dece. Inkluzija, nasuprot integraciji, podrazumeva prihvatanje deteta onakvog kakvo ono jeste, njegovo stavljanje u središte zbivanja, stvaranje mogućnosti da dete prema svojim kriterijumima, sposobnostima i interesovanjima učestvuje u vaspitno-obrazovnom procesu i da sarađuje sa ostalima. Ostvarivanje koncepta inkluzije, između ostalog, podrazumeva stvaranje društvene zajednice u kojoj se podstiču i poštuju prethodna iskustva, znanja, tj. postignuća deteta. Inkluzija, stoga, predstavlja preobražaj, ne samo vaspitno-obrazovnih institucija, već i društvene zajednice u celini. Njen preduslov, ali i posledica, jeste promena ličnih stavova prema deci sa posebnim potrebama. Način da se to postigne jeste stvaranje uslova u 
kojima će doći do interakcije između dece sa i bez teškoća u razvoju (StanisavljevićPetrović, 2013; Vujačić, 2005). Inkluzija, za razliku od integracije, podrazumeva obimnije promene u redovnom sistemu obrazovanja i izlaženje u susret posebnim potrebama dece kroz promenu kurikuluma, unapređenje obrazovanja i stručno usavršanje vaspitača, nastavnika i stručnih saradnika, promenu i unapređenje tehničke opremljenosti vaspitno-obrazovnih ustanova i niz drugih promena (Karić, 2004; Rado i sar., 2013; Stanisavljević-Petrović i Lukić, 2013; Stančić i Stanisavljević-Petrović, 2013; Vujačić, 2005).

\section{Mogućnosti ostvarivanja inkluzije u školi}

Postoje brojni razlozi koji govore u prilog ostvarivanja inkluzije za decu sa posebnim potrebama u okviru redovnih škola. Autorka Vujačić (2005) ukazuje na sledeće:

1) ostvarivanje prava na obrazovanje dece sa posebnim potrebama zajedno sa vršnjacima, čime se stvaraju uslovi za zadovoljavanje brojnih ljudskih potreba, koje ova deca, u uslovima socijalne izolacije, nisu u mogućnosti da ostvare;

2) omogućavanje deci sa posebnim potrebama da ostanu sa svojim roditeljima. Uključivanje dece sa posebnim potrebama u specijalne škole često podrazumeva njihovo odvajanje od porodice i promenu mesta stanovanja, dok se uključivanjem dece sa posebnim potrebama u redovne obrazovne institucije ovo pravo ostvaruje;

3) podsticanje vaspitača i nastavnika da primenjuju različite metode $i$ strategije u radu, kako bi adekvatno odgovorili potrebama sve dece;

4) stvaranje mogućnosti za otkrivanje očuvanih potencijala deteta, kao osnove za vaspitno-obrazovni rad sa decom sa posebnim potrebama i njihovo osposobljavanje za što samostalniji život;

5) menjanje negativnih stavova vaspitača, nastavnika, ostale dece i roditelja prema deci sa posebnim potrebama, usled veće informisanosti i sticanja iskustva kroz interakciju sa ovom decom.

Da bi ovaj reformski proces bio svrsishodan, potrebno je imati u vidu sledeće pretpostavke uspešnog inkluzivnog obrazovanja dece i mladih sa posebnim potrebama: deca sa posebnim potrebama bi trebalo da dobiju više nego u specijalnim školama; deca u redovnim školama ne smeju ništa izgubiti; učenici, roditelji i nastavnici bi trebalo da u redovnim školama prihvate decu sa posebnim potrebama u redovnoj nastavi; nužno je stvoriti sve potrebne kadrovske, materijalne i organizacione pretpostavke; trebalo bi predvideti sve rizike i sprečiti neželjene posledice (Suzić, 2008).

Za uspeh inkluzije u školskom kontekstu potrebno je ostvariti određene preduslove. Takvi preduslovi, između ostalih, podrazumevaju: 1) proces uklanjanja prepreka u učenju i socijalnoj participaciji, 2) socijalnu prihvaćenost deteta sa posebnim potrebama i njegov doživljaj pripadnosti grupi, i 3) prilagođavanje škole posebnim obrazovnim potrebama učenika. Inkluzija, između ostalog, označava izgradnju zajednice u kojoj se podstiču i poštuju prethodna iskustva, znanja, odnosno postignuća deteta (Stanisavljević-Petrović i Lukić, 2013). 
Neophodno je prethodno pripremiti vaspitno-obrazovne ustanove za ostvarivanje modela inkluzije u obrazovanju, pri čemu možemo razlikovati fizičku od socijalne pripremljenosti škole. Pod fizičkom pripremljenošću škole podrazumeva se da su školske prostorije dostupne i prilagođene potrebama svih učenika, kao i da škola poseduje potrebnu asistivnu tehnologiju - adekvatna nastavna sredstva uz čiju primenu bi bilo omogućeno deci i mladima sa invaliditetom da određeni zadatak uspešnije ostvare. Socijalna pripremljenost škole podrazumeva stvaranje pozitivne atmosfere, koja je podržavajuća u načinu organizovanja aktivnosti koje omogućavaju deci i mladima da se međusobno upoznaju i imaju mogućnosti za lični razvoj, kontakte, integraciju u zajednicu i socijalizaciju. Pored toga, školska sredina pruža svojevrsnu podršku deci i mladima sa teškoćama u razvoju u delu informisanja i aktivnog uključivanja u raznovrsne aktivnosti u školi i neposrednoj lokalnoj zajednici. U tom smislu, pripremljenost škole podrazumeva i njenu otvorenost i spremnost za saradnju sa različitim ustanovama, udruženjima i drugim akterima lokalne sredine (Stanisavljević-Petrović, 2013; Stanisavljević-Petrović i Lukić, 2013). Ostvarivanju prava na obrazovanje sve dece, pa i dece sa posebnim potrebama, doprinose sledeći faktori školske sredine: stavovi i ličnosti nastavnika, celokupni etos škole, sadržaji nastavnih predmeta, načini komuniciranja sa učenicima, metode i oblici rada, učešće učenika u odlučivanju, vannastavne aktivnosti, učenički parlament i dr. (Gajić, 2011, prema Kostović i sar., 2011: 11).

Trebalo bi imati u vidu specifičnosti inkluzivnog obrazovanja koje zahtevaju da se u vaspitno-obrazovnom radu sa decom sa posebnim potrebama, pored opštih pedagoških principa primenjuju i specifični principi. Ukazujući na principe inkluzivnog vaspitanja i obrazovanja, Suzić (2008) naglašava njihovu specifičnost u odnosu na sve druge pedagoške principe, koji u odgovarajućoj meri važe i za decu sa posebnim potrebama. Moguće je razlikovati sledeće principe inkluzivnog vaspitanja i obrazovanja: 1) princip socijalne prihvaćenosti i podrške, kojim se ukažuje na važnost socijalne prihvaćenosti dece sa posebnim potrebama od strane vršnjaka i socijalne podrške u procesu vaspitanja i obrazovanja ove dece; 2) princip rane prevencije i rehabilitacije, koji se odnosi na rano otkrivanje i dijagnostifikovanje posebnih potreba deteta, kao osnova rane intervencije koja ima za cilj sprečavanje ili ublažavanje posledica po dete koje posebne potrebe mogu izazvati; 3) princip individualizacije, koji je od naročite važnosti za decu sa posebnim potrebama; 4) princip funkcionalnog razvoja sposobnosti, koji se odnosi na razvijanje prirodno datih sposobnosti dece sa posebnim potrebama putem njihovog stavljanja u funkciju, u cilju razvoja i usavršavanja uočenih sposobnosti; 5) princip stimulacije i kompenzacije, koji se odnosi na važnost adekvatnog motivisanja dece sa posebnim potrebama. Inkluzivno obrazovanje ne podrazumeva uvek uključivanje sve dece sa posebnim potrebama u redovne škole, već takva odluka zavisi od vrste i stepena oštećenja i od uslova koji postoje u vaspitno-obrazovnoj ustanovi. Uključivanje se preporučuje samo ukoliko je to zaista $\mathrm{u}$ interesu deteta sa posebnim potrebama i ostale dece. Moguće kontraindikacije odnose se na decu sa višestrukim smetnjama i decu sa autizmom (Vujačić, 2005). 
Svakako, vaspitači, odnosno nastavnici, predstavljaju centralne figure od čijeg zalaganja i osposobljenosti zavisi uspeh inkluzije. Vaspitači i nastavnici predstavljaju osobe koje su od ključne važnosti za pružanje podrške i pomoći deci sa posebnim potrebama u suočavanju sa izazovima koje sa sobom nosi pohađanje redovne škole (fizičkim, akademskim, socijalnim i emocionalnim). Brojni faktori određuju odnos nastavnika prema učenicima s posebnim potrebama, od kojih se najčešće navode: stavovi nastavnika prema inkluzivnom obrazovanju i prema deci s posebnim potrebama, osobine ličnosti nastavnika, uloge nastavnika, relevantne kompetencije, motivisanost nastavnika, pozitivno lično iskustvo u radu sa decom sa posebnim potrebama, privatno iskustvo sa osobama sa posebnim potrebama (Jurišin i sar., 2012; Kostović i sar, 2011; Hrnjica, 1997, Jamieson, 1984, Bender et al., 1995, Chow \& Winzer, 1992, prema Rajović i Jovanović, 2016: 93; Rajović i Jovanović, 2016; Stančić i Stanisavljević-Petrović, 2013). Od stava nastavnika prema inkluzivnom obrazovanju i prema deci sa posebnim potrebama zavisi njihova angažovanost, kvalitet odnosa koji će uspostaviti kako sa detetom tako i s njegovim roditeljima. Njihovo osećanje neadekvatnosti, nedostatka samopouzdanja može biti značajna prepreka inkluzivnom obrazovanju. Pored toga, ponašanje nastavnika predstavljaće model za ponašanje druge dece u odeljenju i uticaće na formiranje sistema vrednosti kod druge dece, što je preduslov za stvaranje klime prihvatanja i tolerancije u odeljenju (Rajović i Jovanović, 2016).

Pored vaspitača i nastavnika direktno angažovanih na realizaciji individualnog obrazovnog plana, u svrhu realizacije inkluzivnog obrazovanja u našim školama postoje Stručni tim za inkluzivno obrazovanje i Tim za pružanje dodatne podrške konkretnom detetu koje se školuje prema Inkluzivnom obrazovnom planu (Pravilnik o bližim uputstvima za utvrđivanje prava na individualni obrazovni plan, njegovu primenu i vrednovanje, 2009). Svakako, za uspeh inkluzije važna su i motivisanost, zalaganja i kompetentnost i ostalog školskog osoblja, kao i stručnjaka odgovarajućih profila izvan škole (lekara specijalista, defektologa, socijalnih radnika, nadležnih ministarstava, lokalnih vlasti, domaćih i međunarodnih nevladinih organizacija i dr.) (Kostović i sar, 2011; Rajović i Jovanović, 2016).

Osim toga, ključnu ulogu u ostvarivanju inkluzije u obrazovanju imaju i vršnjaci dece sa posebnim potrebama. Generalno gledano, rezultati istraživanja pokazuju da deca koja su čulno, motorički, telesno ili intelektualno ometena doživljavaju teškoće u svom socijalnom razvoju i u uspostavljanju uspešnih vršnjačkih odnosa. Iako, njihove vršnjačke interakcije imaju slične razvojne obrasce kao interakcije dece tipičnog razvoja, kvalitet njihove interakcije se razlikuje. Takvoj deci potrebna je dodatna pomoć kako bi naučila da uspostave adekvatne odnose sa vršnjacima (Gašić-Pavišić, 2002; Vukajlović, 2011). Pored toga, jako je važno pripremiti drugu decu, kao i njihove roditelje, za interakciju sa decom sa posebnim potrebama. Zbog ključne uloge vršnjačke prihvaćenosti i osećaja pripadnosti grupi za razvoj svakog učenika, jako je važno raditi na izgrađivanju pozitivnih stavova prema takvoj deci i na podsticanju pozitivnih vršnjačkih interakcija (Đević i sar., 2009; Rajović i Jovanović, 2016; Stanisavljević-Petrović i Lukić, 2011). 
Iako su u našoj zemlji izvršeni određeni pomaci u oblasti inkluzivnog obrazovanja, trebalo bi, ipak, napomenuti da rezultati dosadašnjih istraživanja pokazuju da se naša škola, zbog brojnih razloga, nalazi na pozicijama delimične inkluzije. Neki od tih razloga su: nepostojanje odgovarajućih nastavnih sredstava i pomagala neophodnih za kvalitetan rad sa decom sa posebnim potrebama, nesaradnički odnosi između nastavnika i pedagoga, nedovoljna angažovanost dela nastavnog osoblja (Stanisavljević-Petrović i Lukić, 2011), nespremnost nastavnika da prihvate decu sa posebnim potrebama, neadekvatna pripremljenost nastavnika za rad sa decom sa posebnim potrebama, osećaj nedovoljne lične kompetentnosti kod nastavnika, negativni stavovi prema osobama sa posebnim potrebama (Rajović i Jovanović, 2016), i dr.

Primera radi, u istraživanju autorki Spasenović i Matović (2005) koje je realizovano sa ciljem da se utvrdi kako nastavnici u Srbiji procenjuju vlastitu pripremljenost za rad s decom sa smetnjama u razvoju, kao i kakva je, prema njihovom mišljenju, uloga inicijalnog obrazovanja u osposobljavanju za rad u inkluzivnim uslovima pokazalo se da većina nastavnika procenjuje da nije adekvatno osposobljena za rad s decom sa smetnjama u razvoju, kao i da inicijalno obrazovanje nije mnogo doprinelo njihovoj pripremljenosti za rad u tom domenu. Uzorak je činilo 212 nastavnika razredne i predmetne nastave iz pet osnovnih škola sa teritorije grada Beograda. Ustanovljeno je da ne postoje statistički značajne razlike između nastavnika razredne i predmetne nastave u proceni vlastite pripremljenosti, ali su one registrovane u procenama doprinosa inicijalnog obrazovanja njihovoj osposobljenosti za rad s decom sa smetnjama u razvoju, pri čemu su učitelji u nešto povoljnijem položaju.

\section{Zaključak}

Reformskim procesima u našem školskom sistemu stvoreni su određeni preduslovi za uvođenje inkluzivnog obrazovanja u vaspitno-obrazovne institucije. Doneta je određena pravna regulativa i učinjeni si izvesni pozitivni koraci u pravcu uspešne implementacije inkluzivnog obrazovanja. Ipak, čini se da spremnost naših škola za prihvatanje procesa inkluzije još uvek nije dostigla svoj vrhunac. Iako je došlo do velikih promena u sferi obrazovanja, iako je savremeno, modernizovano drušvo uticalo na brojne promene u svim sferama društva, čini se da naša škola nije još u potpunosti spremna za ostvarivanje inkluzije. Ostvarivanje procesa inkluzije je izuzetno složen proces koji zahteva istinsku posvećenost svih ključnih aktera. Međutim, može se reći da postoji dobra osnova za dalji razvoj procesa inkluzije na nivou celokupnog društva, kao i u obrazovnim ustanovama.

Možemo zaključiti da je inkluzija u našim škola delimično sprovedena. Razloge za to možemo tražiti u nedovoljnoj opremljenosti samih škola odgovarajućim prostorijama, kao i sredstvima koja bi olakšala rad nastavnicima i učiteljima. Takođe, razloge možemo pronaći u nedovoljnoj pripremljenosti sredine za prihvatanje dece sa posebnim potrebama, neprihvaćenosti dece sa posebnim potrebama od strane vršnjaka, niskom socijalnom statusu učenika sa posebnim potrebama u odeljenjima 
redovnih škola, nedovoljnoj obučenosti kadra za rad sa ovom decom, predrasudama velikog broja nastavnika, učitelja itd.

Da bi se uspešno sprovodio proces inkluzije, potrebno je raditi na poboljšanju uslova za rad, obezbeđivanju neophodnih sredstava za rad, unapređivanju kompetencija nastavnika i učitelja za rad sa decom sa posebnim potrebama, unapređivanju kompetencija i drugog školskog osoblja, unapređivanju saradnje među školskim osobljem, spremnosti vršnjaka za prihvatanje dece sa posebnim potrebama, uspostavljanju uspešne saradnje sa roditeljima sve dece, otvorenosti škole kao institucije i dr. Inkluzija neće biti uspešno sprovedena ukoliko u školi ne vlada pozitivna atmosfera, ukoliko nastavnici nisu stekli potrebne kompetencije za rad sa decom sa posebnim potrebama, ukoliko vršnjaci imaju negativan stav prema deci sa posebnim potrebama i ukoliko između samih stručnih saradnika ne postoji adekvatna saradnja i podrška.

Osim toga, za uspešnu inkluziju neophodne su: dalje promene u širem društvenom kontekstu u pogledu podizanja svesti o osobama sa posebnim potrebama, povećana materijalna ulaganja u opremanje društvenih ustanova u pogledu njihove dostupnosti osobama sa posebnim potrebama, otklanjanje stereotipa i predrasuda prema osobama sa posebnim potrebama, stvaranje okolnosti za sticanje pozitivnog iskustva kroz interakcije sa osobama sa posebnim potrebama itd.

\section{Literatura}

Đević, R., Đerić, I. i Stanišić, J. (2009). Spremnost učenika redovne škole da prihvate decu s teškoćama u razvoju. Nastava $i$ vaspitanje, 58(4), 561-578.

Đukić, M. i Đermanov, J. (2011). Inkluzivno obrazovanje kao pedagoški problem. U B. Jevtić (ur.) Vaspitanje za humane odnose - problemi i perspektive, zbornik radova (279-291). Niš: Filozofski fakultet.

Gašić-Pavišić, S. (2002). Vršnjačko socijalno ponašanje dece sa smetnjama u razvoju. Nastava $i$ vaspitanje, 51(5), 452-469.

Ivančić, Đ. (2013). Diferencirana nastava u inkluzivnoj školi. Beograd: Eduka.

Jurišin, S., Klemenović, J. i Marković, B. (2012). Stavovi nastavnika prema inkluzivnom obrazovanju osoba sa razvojim teškoćama i invaliditetom. U M. Đukić (ur.): Inkluzivno obrazovanje: obrazovanje za sve - zbornik radova (43-56). Novi Sad: Filozofski fakultet.

Karić, J. (2004). Stavovi prema uključivanju dece sa posebnim potrebama u redovan sistem obrazovanja. Nastava i vaspitanje, 53(1), 142-146.

Kostović, S. i sar. (2011). Razvoj inkluzivne obrazovne prakse u školskom kontekstu. U M. Đukić (ur.) Inkluzivno obrazovanje od pedagoške koncepcije do prakse - zbornik radova (1-14). Novi Sad: Filozofski fakultet.

Kovačević, J. (2011). Deca sa posebnim potrebama u redovnoj školi. Beograd: Učiteljski fakultet.

Pravilnik o bližim uputstvima za utvrđivanje prava na individualni obrazovni plan, njegovu primenu i vrednovanje (2009). ,Službeni blasnik RS”, broj 72/09. 
Rado, P. i sar. (2013). Koliko je inkluzivna naša škola? - Priručnik za samoevaluaciju i spoljašnju evaluaciju inkluzivnosti škole. Beograd: Centar za obrazovne politike.

Rajović, V. i Jovanović, O. (2016). Profesionalno i privatno iskustvo sa osobama s posebnim potrebama i stavovi nastavnika redovnih škola prema inkluziji. Psihološka istraživanja, 13(1): 91-106.

Spasenović, V. i Matović, N. (2015). Pripremljenost nastavnika razredne i predmetne nastave za rad s decom sa smetnjama u razvoju. Nastava $i$ vaspitanje 64(2): 207-222.

Stančić, M. i Stanisavljević Petrović, Z. (2013). Mišljenja vaspitača o koristima od inkluzije i načinima njenog ostvarivanja. Specijalna edukacija i rehabilitacija (3): 353-369.

Stanisavljević Petrović, Z. (2013). Implementation of the inclusive educational model in schools. Facta universitatis - Series: Philosophy, Sociology, Psychology and History 12(1): 29-40.

Stanisavljević Petrović, Z. i Lukić, G. (2011). Inkluzivno obrazovanje u očima nastavnika. $\mathrm{U}$ : B. Jevtić, (ur.) Vaspitanje za humane odnose - problemi i perspektive, zbornik radova (162-176). Niš: Filozofski fakultet.

Stanisavljević Petrović, Z. i Lukić, G. (2013). Pripremljenost školske sredine za proces inkluzije. Pedagogija 68(1): 68-78.

Suzić, N. (2008). Uvod u inkluziju. Banja Luka: XBS.

Vujačić, M. (2005). Inkluzivno obrazovanje - teorijske osnove i praktična realizacija. Nastava $i$ vaspitanje 54(4-5): 483-496.

Vukajlović, B. (2011). Učenici kao faktor implementacije inkluzivnog obrazovanja. U B. Jevtić (ur.) Vaspitanje za humane odnose - problemi i perspektive, zbornik radova, 310-320. Niš: Filozofski fakultet.

Zakon o osnovama sistema obrazovanja i vaspitanja (2009). „Službeni glasnik RS”, br. $72 / 2009$.

\title{
THE POSSIBILITIES OF IMPLEMENTATION OF INCLUSION IN THE SCHOOL CONTEXT
}

\author{
Marija Marković \\ University of Niš , Faculty of Philosophy in Niš, Department of Pedagogy
}

\begin{abstract}
The paper points to the possibilities of implementation of the concept of inclusive education in the school context, as an integral part of the reform of the school system in our country. It is pointed out to the ways of defining the notion of inclusion, the types of special needs of children, as well as the ways of implementation of the concept of inclusive education in our country. Special attention is paid to pointing to the specificity of different models of education of children with special needs. From a critical point of view, issues related to the potential of the school context in achieving inclusion are analyzed and discussed. The central part of the paper is dedicated to
\end{abstract}


indicating the real possibilities of schools to respond to the needs and challenges of achieving inclusive education, in terms of indicating the necessary prerequisites, the advantages and disadvantages of our school context in that domain, as well as the necessary changes in the school context. Implementation of inclusion in educational institutions constitutes the basic for the creation of an inclusive society, wherein changes in school are considered as a priority in that process.

Key words: school, inclusive education, children with special needs, teachers, peers.

\section{Citiranje članka:}

Marković, M. (2017). Mogućnosti ostvarivanja inkluzije u školskom kontekstu. Godišnjak za pedagogiju, 2(1), 51-62. 